\title{
Analysis of Xi Jinping's Multidimensional Ecological View
}

\author{
Jia-Lin LIU ${ }^{1, a}$ and Yi-Fei MA ${ }^{2, b}$ \\ ${ }^{1}$ School of Business, Human Institute of Humanities, Science and Technology, Hunan Loudi, \\ 417100, China \\ ${ }^{2}$ School of Business Administration, Zhongnan University of Economics and Law, Hubei Wuhan, \\ 430073, China \\ aliujialin0738@163.com and 340375178@qq.com, b775694276@qq.com
}

\begin{abstract}
Keywords: Green Transformation, Xi Jinping's Ecological Thought, Ecology View, Ecological Civilization
\end{abstract}

\begin{abstract}
In order to explore the profound significance of Xi Jinping's ecological thoughts, the article takes Xi Jinping's ecological thoughts as the research object, uses literature analysis, comparative analysis and other methods to find origins from Chinese traditional ecological thoughts, Marxist ecological thoughts, and the ecological ideology of the Communist Party of China. After systematically sorting out Xi Jinping's ecological thoughts, a "Seven-in-One” ecological outlook system, including ecological civilization outlook, ecological development outlook, ecological livelihood outlook, ecosystem view, ecological rule of law outlook, ecological bottom line outlook, and ecological international outlook, was formed. Among them, the concept of ecological civilization is the guiding ideology, the concept of ecological development is the core, the concept of ecological livelihood is the foundation, and the concept of ecosystem, the concept of ecological rule of law, both the concept of ecological bottom line and the concept of ecological internationalization are the means to achieve this.
\end{abstract}

\section{Introduction}

The green transformation is based on the analysis of the current international eco-environmental changes and the basic conclusions drawn from the Marxist ecological thoughts in practice in China. It is also a summary of the historical experience and strategic deployment of the Chinese Communist Party's long-term development process. Since the 18th National Congress of the Communist Party of China, General Secretary Xi Jinping has proposed a series of new viewpoints, new conclusions, and new requirements for green development and ecological environment protection from different perspectives and levels in a new perspective, and has continuously expanded our party's idea of ecological governance during recent 5 years. In December 2016, Xi Jinping stated at the National Conference on Promotion of Ecological Civilization Construction that we must build the "four pillars and eight pillars" of the ecological civilization system as soon as possible, and incorporate ecological civilization into the institutionalized and legalized track. This analyzes the aspects of ecological environmental governance, the relationship between humans and nature, and the construction of ecological civilization and economic and social development. It also reflects the core content of Xi Jinping's ecological thinking and deepens the connotation of Marxist ecological thoughts in China. So, what are the core contents of Xi Jinping's ecological thoughts and what kind of inside logical relationship exists among them? These are the points that this article needs to explore, as it has a great theoretical and practical significance to promote the development of Xi Jinping's concept of administering the country.

\section{The Evolutionary Origin and Foundation of Xi Jinping's Ecological View}

The evolution of Xi Jinping's ecological outlook is a historical process of absorbing historical lessons and absorbing development essence. Essentially speaking, it is actually the evolution of the specific practice of Marxism in China. It is also the crystal of the Chinese Communist Party's ecological concept refinement over the years and reflects the essence of China's traditional 
ecological ideas.

\section{The Inheritance of Ancient Chinese Ecological Thoughts}

On the one hand, the Confucianism in China advocates the ecological thought of "Unity of Heaven and Earth", it analyzes the relationship between man and nature and determine the status of mankind in the world from the perspective of ecological philosophy. Dong Zhongshu, a famous Confucian scholar of the Han Dynasty, first expounded the basic connotation of "Unity of Heaven and Man." He believed that mankind is only part of the universe, and that man and nature are closely related to each other [1]. On the other hand, the traditional ecological concept is also a way to propose ecological environmental protection from the perspective of methods. It reflects the ecological point of view that the people follow the natural laws to arrange production, and shows the symbiotic relationship between man and nature. The relationship among human beings and between nature and humans that discussed by $\mathrm{Xi}$ Jinping has been influenced by traditional ecological thoughts, especially in terms of ecological rule of law, ecosystems, and ecological security.

\section{The Spread of Marxist Ecological Thought}

The Marxist ecological thoughts expounded more on the relationship between man and nature and argued that nature is the basis for human survival and development. The natural world has gradually become part of the human life supporting system and needs to be more cherished. Marx also believes that ecological civilization is the ultimate choice for communist society. As it can form a whole among nature, people, and society coherently. Marx's ecological view has revealed the dialectical unity relationship between human and nature, and points out that human transformation of nature needs to follow and maintain the law of nature, keeps the balance of the ecosystem, acts according to the objective law, and finally realizes the harmony and unity of man and nature. This reflects the main connotations of Xi Jinping's ecological outlook, and also embodies the People, Time, and Innovation of Xi Jinping's ecological environment protection and sustainable development.

\section{The Inheritance of the Ecological Thoughts of the Communist Party of China}

Mao Zedong inherited and developed Marxist ecological thoughts, who tooks environmental protections work as a key task of socialist construction. Deng Xiaoping inherited and developed the ecological view of Marxism, who suggested take ecological protection and construction as a basic national policy. Jiang Zemin proposed that protecting the environment is essentially protecting productivity, who thought it is necessary to take ecological and environmental protection into account while paying attention to the coordinated development of economy and society. In the 17th National Congress of the Communist Party of China, Hu Jintao first put forward the idea of ecological civilization construction. This is in line with the eighteen "Five-in-One" development layouts. All of these are providing ideas and theoretical support to the formation of Xi Jinping's ecological civilization construction thought.

\section{The Basic Connotation of Xi Jinping's Seven-in-One” Ecological Concept}

After the 18th National Congress of the CPC, the Party Central Committee headed by Xi Jinping gradually strengthened the practice of localizing Marxist ecological thoughts and gave new ideological connotations to it. Xi Jinping's ecological thoughts fully inherited and absorbed the essence of China's traditional ecological culture ideology, the Marxist ecological thought, and the ecological ideology of the Chinese Communist Party over the ages, and formed a new ecological outlook system.

\section{The Ecological Civilization Outlook}

Without ecological support, there will be no healthy development of human civilization [2]. The key to the construction of ecological civilization is to handle the relationship between economic 
construction and ecological protection, let people and nature coexist in harmony, and create a win-win path both for economic development and ecological civilization construction. Xi Jinping's ecological civilization concept is to pay attention to the mutual assistance relationship between man and nature. He advocates that natural laws should be followed; resource conservation and ecological environment protection should be strictly enforced, consciously increases the development of green economy, and actively integrate ecological civilization construction into all aspects of economic, cultural, social and political construction. In a word, Xi Jinping's concept of ecological civilization indicates the direction of economic and social development, leads people to live in harmony with nature, and provides a solid ecological foundation for sustainable social development.

\section{The Ecological Development Concept}

$\mathrm{Xi}$ Jinping's ecological development concept elaborates the dialectical thinking relationship between economic and social development and the ecological environment. The concepts of ecological development, for example, "To firmly establish the opinions that protect the ecological environment is to protect the productive forces and improve the ecological environment is to develop productive forces" [3] and "Lucid waters and lush mountains are invaluable assets" [4]. Xi Jinping's ecological development concept believes that ecological environment and economic development are mutually reinforcing and not opposing contradictions, which points out that in the event of economic and ecological contradictions, and provides a theoretical guidance for the coordinated development of China’s economy, society and l ecological environment protection.

\section{The Ecological Livelihood}

According to the level of Maslow's needs, people will have a strong desire for high-level needs after the basic survival needs are met. Nowadays, the ecological demand has gradually become the people's major livelihood needs. Xi Jinping proposed that "a good ecological environment is the most equitable public product, and it is the most well-being of the people's livelihood.” It regards the ecological environment as the largest public product and allows people to generally feel the benefits of a good ecological environment. Xi Jinping's ecological livelihood concept reflects the close relationship between ecology and people's livelihood, enriches the basic connotation of people's livelihood, and also reflects the people's expectation of "beautiful China". Meanwhile, it not only pays attention to the ecological livelihood of the people, but also pays attention to the ecological livelihood of generations and creates a good ecological environment for future generations, which highlights people-oriented values.

\section{The Ecosystem View}

People must not divide the ecological environment artificially. Instead, that should maintain the ecological environment as a whole. Xi Jinping emphasizes to follows the self-evolving rules of the ecosystem and proposes that the overdrawn resources and environment be gradually cultivated and then restored through the self-ecosystem. Xi Jinping's ecological system requires us to follow its objective laws in the process of ecological governance and regard ecological civilization construction as "system engineering". It is the sublimation of the understanding of the sustainable development of the economy, society, resources, and environment. It is also the deepening of the understanding of the construction of ecological civilization and enriches the party's governing philosophy and governance strategies.

\section{The Ecological Rule of Law}

Eco-environmental problems are often affected by multiple factors. To effectively solve ecological environment governance, it is necessary to explore methods from the perspective of social systems. Xi Jinping stated on the sixth collective study of the Political Bureau of the Central Committee that "Only by implementing the strictest system and the strictest legal system can we provide a reliable guarantee for the construction of ecological civilization.”[5] Xi Jinping's concept of ecological rule of law aims to protect the ecological environment and promote the development of ecological civilization through the legal system, to guide all stakeholders to focus on following the relevant 
laws of the ecosystem as the main theme and strictly follow the objective laws, then work together to create a beautiful "ecological dream".

\section{The Ecological Bottom Line}

Ecological security is the cornerstone of national security. As the "bottom line" of natural security, ecological security is tandem with all aspects of economic and social development. Xi Jinping attaches great importance to ecological security, and he believes that maintaining the ecology within a reasonable safety boundary requires establishing the concept of "ecological protection red line". The ecological elements have gradually become an increasingly important factor in China's modernization construction and have rapidly evolved into an important factor affecting the rapid economic and social development of our country. Xi Jinping's ecological bottom line concept embodies an important strategic position for ecological security. Maintaining a good ecological environment has become a forceful point for China's good image. The ecologically safe and Green Great Wall has been gradually built to provide ecological security for sustainable development.

\section{The Ecological International View}

The cross-border and trans-spatial distribution has become the main characteristic of the current ecological environment, so the ecological environment issue has become a truly global problem. The Chinese government has been actively participating in international environmental protection cooperation over the years. Xi Jinping has been particularly prominent and valued in international ecological cooperation. The ecological international outlook put forward by $\mathrm{Xi}$ Jinping is to strengthen cooperation with ecological environmental governance in various countries with a strategic vision of internationalization and jointly safeguard human ecological harmony. Through diversified platforms and channels, cooperation between major countries has been used to promote multinational cooperation. This is a kind of destiny in the ecological community, which also shows the new thinking of "re-cooperation, tower platform, mutual trust, consensus, and practical effect".

\section{The Intrinsic Logical Relations of Xi Jinping’s “Seven-in-One” Ecological Concept}

$\mathrm{Xi}$ Jinping's ecological thinking is to realize the harmony between man and nature and also among the people; and it is also the ecological foundation for realizing the "Chinese Dream". It has been given a new ideological connotations and formed an ecological view system (Figure 1), including seven aspects, like ecological civilization concept, ecological development concept, ecological livelihood concept, ecosystem view, ecological rule of law concept, ecological bottom line view and ecological international outlook. This is complementary and linked mutually.

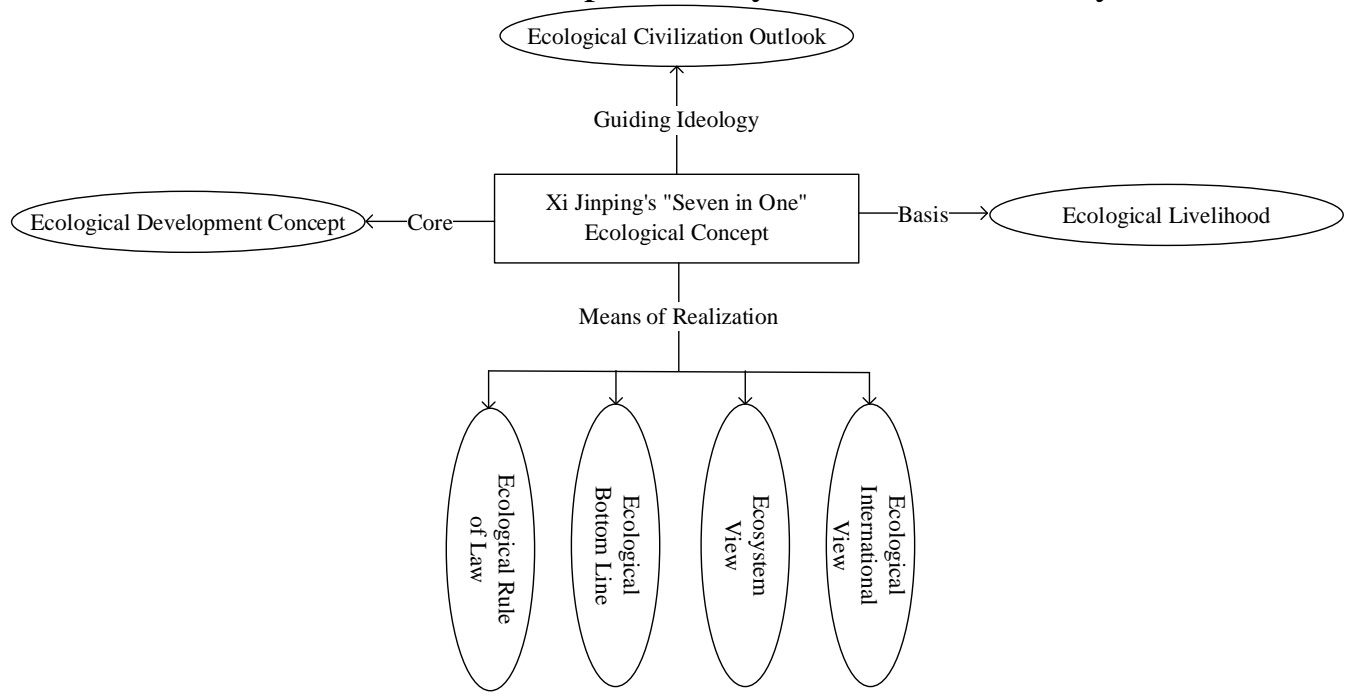

Fig. 1 Xi Jinping’s “Seven-in-One” Ecological Concept

First, Xi Jinping's ecological civilization concept is the guiding ideology of the "Seven-in-One" 
ecological outlook system. Ecological and environmental protection-related economic and social activities and construction must all focus on ecological civilization and follow the rules of ecological civilization construction. As the concept of ecological civilization demonstrates the relationship between ecology and civilization from the historical height of the history of human civilization. It reflects the central position and core role of the concept of ecological civilization in the entire ecological construction to guide the other six ecological concepts.

Second, Xi Jinping's ecological development concept is the core of the "Seven-in-One" ecological outlook system. The long-term sustainable development of ecological environment protection is inseparable from the support of economic development. Similarly, the realization of Xi Jinping's ecological outlook system also requires economic protection. Xi Jinping proposes innovatively that eco-environmental resources are productivity and provide sufficient incentive for ecological and environmental protection, which integrates ecology and economy to ensure social development with a unified body.

Third, Xi Jinping's concept of ecological livelihood is the basis of the "Seven-in-One" ecological outlook system. The ecological thought of Marx's political economy is to provide welfare for the people. Xi Jinping's ecological concept system reflects the overall direction and development ideas of China's ecological environment protection. The realization of this system must also be rooted in the masses and fully consider people's livelihood.

Fourth, Xi Jinping's view of ecosystem, ecological bottom line, ecological legal concept, and ecological international outlook are the means to realize the "Seven-in-One" ecological concept system. Xi Jinping's ecological outlook system is to treat ecological environment governance as a systematic project, and it must be implemented in an integrated and coordinated strategic deployment. The ecological protection red line should be used as the bottom line for ecological environmental governance. When dealing with the relationship between ecology and economic development, this basic baseline cannot be touched to build a safety barrier for it. Meanwhile, to rationalize the ecological environment governance mechanisms and systems, we should implement effective and reasonable laws and regulations to ensure the smooth realization of ecological governance. Finally,we must strengthen international cooperation in ecological and environmental governance and view environmental development issues in an international perspective.

All in all, the "Seven-in-One" ecological outlook system embodies the basic connotation of Xi Jinping's ecological thoughts and is also an important theoretical contribution to the sinicization of Marxist ecological thoughts. It provides theoretical support and guarantee for the construction and development of ecological environment protection in China; and it also provides an ecological foundation for the realization of "Beautiful China".

\section{Conclusions}

The "Seven-in-One" ecological outlook system is the main embodiment of the core content of Xi Jinping's ecological thoughts. It is the main achievement of the sinicization of the Marxist ecological thoughts, and it is also a major theoretical crystallization of the Chinese Communist Party's long-term practice. Xi Jinping's ecological outlook system has clearly clarified the relationship between ecology and economy and also between ecology and civilization. Which clarified that ecology is an important assertion of productivity, the core foundation of the ecological outlook system is people's livelihood. It is necessary to actively maintain and protect the people's ecological needs and health. Through the international cooperation in ecological environmental governance, the establishment of sound ecological management regulations and systems, and the establishment of ecological protection barriers, etc., which is help to manage the ecological environment from the perspective of a systematic view and to provide ecological protection for the "Beautiful China” and "The Chinese Dream”.

\section{Acknowledgement}

This research was financially supported by the Ministry of Education Humanities and Social 
Sciences Research Youth Foundation (No. 14YJC790078); the Hunan Provincial Social Science Foundation (No. 16YBX008); the research achievements of Hunan University Science and Technology Innovation Team.

\section{References}

[1] Guan Mingguo, Guan Wei, The contemporary value of Chinese traditional cultural ecology, Environmental Protection, 15 (2013):39-40.

[2] Xu Shuihua, Chen Xi. Multidimensional interpretation of Xi Jinping's ecological thoughts, Seeking Truth, 11 (2014):16-21.

[3] Xi Jinping, Lucid waters and lush mountains are invaluable assets, People’s Daily, 11 (2014).

[4] Propaganda Department of the CPC Central Committee, General secretary Xi Jinping's series of important speech readers, People’s Publishing House, Beijing, 2014, pp.110.

[5] Xi Jinping, Xi Jinping talks about ruling the country, Foreign Language Press, Beijing, 2014, pp.210.

[6] Li Wenji. The first batch of central environmental protection supervision work has been fully launched: up to now, 541 people have been held accountable in 7 places, Legal Evening News, 8 (2016). 